\title{
Financing Public Transport Infrastructures by Means of Value Capture Provided by Its Implementation
}

\author{
Hostilio Xavier Ratton Neto, Romulo Dante Orrico Filho and Herlander Costa Alegre da Gama Afonso \\ Transportation Engineering Program, Federal University of Rio de Janeiro, Rio de Janeiro 21941-914, Brazil
}

\begin{abstract}
A transport infrastructure is not only a trip provision system but a public facility that generates value for companies and for the society through expanding markets or developing cities, creating another perspective for new investments, as well as its own financing. According to this perspective, the financial earnings resulting from the implementation of transport infrastructure can be captured for its own investment. Given the restrictions of society indebtedness, due to social inequalities, scarcity of resources and insufficient fare collection, with the current financial model for public transport infrastructures, the value capture configures as a strategy to be explored to obtain resources. This paper presents the concept of value capture and its connection and relevance with transport infrastructure financing strategies. Applied to the evaluation of the impacts on the surrounding regions of one of the most significant Brazilian transport projects, the improvement and expansion of Belo Horizonte's metro, the provided value capture outcomes open more realistic perspectives for greater engagement of the Public Sector in such projects.
\end{abstract}

Key words: Value capture, infrastructure financing, public transportation, urban development.

\section{Introduction}

According to Barat [1], the historical process that gave form and content to the current urban structure of the biggest Brazilian metropolitan areas, urban evolution and rail transport provision are intimately linked: the railroad's lineal form of territorial structuring has driven the socioeconomic development of the surrounded areas and the neighborhoods. Besides, Aragao [2] detaches the well discussed and documented importance of technical infrastructures for economical growth and e-development [3-8]. In Brazil, several authors [9-13] have accomplished approaching studies about the positive relationships between infra-structural investment, productivity and economical growth. In such context, investments in metro-rail infrastructure appear to be of paramount importance to society, either as part of induction to socio-economic development as a tool for social inclusion and urban structuring, providing other economical and social benefits, such as accessibility

Corresponding author: Herlander Costa Alegre da Gama Afonso, M.Sc., research field: public transport. E-mail: herc_afonso@hotmail.com. and mobility improvement, and pollutant emissions and travel time reduction.

However, one of the biggest financial gains, resulting from public investment, the increase of real estate value, goes to the land owners, without any return to society, fomenting speculation, with adverse effects on urban development, such as reservation of vacant land and even greater segregation of the city space. Due to that, if it was possible to implement a mechanism for the financial recovery of at least a part of the expended public capital from the obtained private benefits, such distortion could be corrected by generating resources to other investments on behalf of the common well-being. Such mechanism actually exists, it is called value capture, as defined by the OECD_Organization for Economic Co-operation and Development [7] in Pedler [14], whereby the responsible agent for the infrastructure development transfers part of the land proprietors' financial gains to society.

Aragão [2] also states that the abundant literature about transit oriented development and value capture provides sufficient evidence not only for the fiscal 
viability of this approach, but also for its limitations and constraints [15-20]. In Brazil, this procedure is already legally possible by several instruments under the Statute of the City [21, 22].

According to Lima Neto [21], this definition of VC (value capture) is an adaptation of the widely internationally discussed capture value concept, which allows the collection of the induced private owned land's profits by the public administration, in its role of the development ruler, to finance urban projects. The fundamental basis of the capture is the concept of surplus value, which is the value or benefit incorporated by urban real estate due to urbanization or normative instruments that delegate an increment on the constructive potential of the land.

Investments in infrastructure are mainly made by the government. Value capture shows how much the increase of the taxes revenues, exclusively due to the project's economical benefits, would cover, in a cash flow, the government's financial commitments. It is therefore a new approach of the financial viability analysis of infrastructure projects, directly related to its true reason of being, that is to promote the economical growth of the served area.

This paper is an exercise to present an evaluation of the recoverable share of the metro-rail infrastructure public financing. Value capture from real estate and income taxes of beneficiary activities of changes on the pattern of land use could finance at least a part of the their own infrastructure investment costs and other public projects. The evaluation was applied to the improvement and expansion plan for the Line 1 of the Belo Horizonte's metro-rail network, in Brazil, considering: (1) the potential collection from profits due to real estate higher market prices; (2) the additional collection of the IPTU (Urban Property Tax) corresponding to the built surface enhancement; (3) the additional collection of the ICMS (Added Value on Goods and Services Tax) and of the ISS (Services Tax) corresponding to the construction activities in the enhanced built surface; (4) the ISSQN (additional collection of the Services of Any Nature Tax) on behalf of service activities generated in the enhanced built surfaces.

\section{A Brief Historical Report of the Belo Horizonte's Metro-Rail Transportation System}

In the late 1970s, the Brazilian Ministry of Transport has decided to develop a project that simultaneously could solve the bottlenecks problem in freight rail lines and provide better urban passenger transport offer in the Belo Horizonte's metropolitan area. In this sense, the project of the metropolitan train of Belo Horizonte was developed. The existing rail track was duplicated and two new tracks were built to a surface metro, aiming to reduce construction costs and solving the problem of the metropolitan area crossing by freight trains.

The first design plans provided a line between the city of Betim, in the east of the metropolitan area, and the São Gabriel district, with a branch to the Barreiro district, totaling $60 \mathrm{~km}$ of dedicated railway tracks (no interference with vehicular traffic and pedestrians), 22 stations, 25 electric trains, workshops, yards, intermodal integration terminals, support facilities, and energy, supervision, control and telecommunications systems. Works began in 1981, scheduled to be achieved in 1986, on a $37 \mathrm{~km}$ long priority section, consisting of the $26.5 \mathrm{~km}$ long Eldorado-São Gabriel and the $10.5 \mathrm{~km}$ long Calafate-Barreiro branches.

However, the available resources were reduced and the schedules were subsequently extended until 1987, when works have practically stopped. Under such conditions, the metro operation comprised only the $12.5 \mathrm{~km}$ long Eldorado-Central section, with seven stations and a fleet of only five trains.

Construction works have resumed in 1991, but with significant changes compared to the original goals:

(1) The Eldorado-Betim branch has been postponed; 
(2) The Barreiro district branch was no longer a priority;

(3) The priority line became the North vector toward the Venda Nova district;

(4) Inclusion of three more stations in the Eldorado-São Gabriel branch: Vila Oeste (and New Bus Station), José Cândido da Silveira and Mines Shopping.

Since 1995, the deployment of Line 1 has gained new force, after the signing of a financing contract with the World Bank. With this funding, the Eldorado-Vilarinho section began to operate in all its extension. At the same time, the Federal Administration has started the Belo Horizonte's metro undertaking transfer process from the CBTU-Brazilian Urban Trains Company, a Federal Government owned company, until then responsible for its construction and operation, to local authorities.

This process, known as the "metro's regionalization", still ongoing in 2010, will be achieved after the assignment of the state of Minas Gerais and the Belo Horizonte and Contagem municipalities as new responsibilities.

\section{General Characteristics of the Belo Horizonte's Metro Line 1 and of Its Influenced Area}

The Belo Horizonte's metro Line 1 has 28.2 kilometers of double track, covering the Belo Horizonte and Betim municipalities. It connects the Northern and Western urban growth vectors-the biggest-of the metropolitan area, but it does not cross the Belo Horizonte's downtown center, it just borders it. It has 19 operating stations, four of them intermodal integration terminals: Eldorado, José Cândido, São Gabriel and Vilarinho. Another intermodal terminal will be built coupled with the future Nova Rodoviária (New Bus Station).

The ongoing negotiations of the metro's regionalization, between the Federal Government, the Government of the state of Minas Gerais and the Belo
Horizonte and Contagem municipalities involve the necessary investments to substantially improve the operating conditions of Line 1 , increasing its capacity and ensuring its better economic performance.

The available data and information were collected from many sources for this evaluation exercise. The geographic and socioeconomic information about the metro's surrounding area were obtained from the IBGE's (the Brazilian Institute of Geography and Statistics) of and the João Pinheiro Foundation (the Minas Gerais state's data and information basis) websites. The metro's sections lengths were taken from the Google Earth maps software. In addition, the forecast of the examined scenarios has required some inferences, adopted by means of consensus among the authors.

For this exercise's purposes, the line was divided in four sections: Novo Eldorado-Nova Rodoviária (5,547 m long), Nova Rodoviária-Central (5,519 m long), Central-São Gabriel (9,316 m long) and São Gabriel-Vilarinho (7,819 m long). The surrounding influenced area was assumed to be $1,600 \mathrm{~m}$ wide alongside the line.

According to Table 1, in 2007, Belo Horizonte had a total of 2,412,937 inhabitants, while Betim counted 415,098 . In the same year, the population of the considered influenced area, corresponding to $13.6 \%$ of the total surface of the city, was 281,997 people (11.7\% of the entire city's population).

Based on these data, the following determinations were made for each section of Line 1 :

(1) Project's influenced area;

(2) Population density in inhab./km, estimated according to the densities of the regions through which the line passes, both in Belo Horizonte and in Betim;

(3) Population of the influenced area, the multiplication of such area by its population density.

Table 2 summarizes such determinations.

The population in the influenced area was calculated and the evolution of the Line 1 demand 


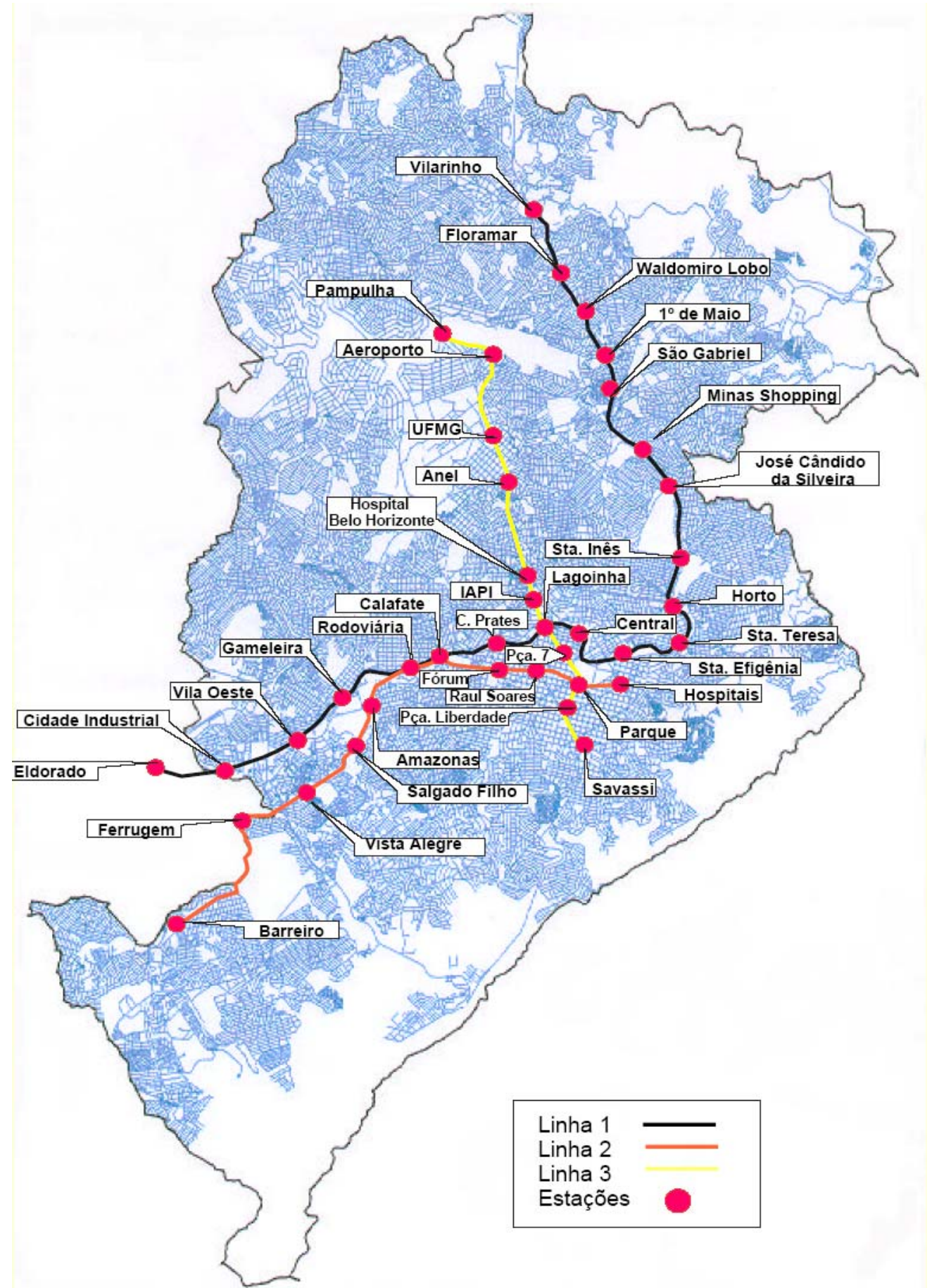

Fig. 1 Belo Horizonte's metro lines.

Table 1 Population, surface and population density in Belo Horizonte, Betim and in the influenced area by the Belo Horizonte's Metro Line 1.

\begin{tabular}{lcccc}
\hline & Belo Horizonte & Betim & Line 1 & Line 1/BH \\
\hline Population in 2007 (inhab.) & $2,412,937$ & 415,098 & 281,997 & $11.7 \%$ \\
Area $\left(\mathrm{km}^{2}\right)$ & 331.0 & 346.0 & 45.1 & $13.6 \%$ \\
Density (inhab./ha) & 72.9 & 12.0 & & \\
\hline
\end{tabular}

Source: IBGE [24]. 
growth rates was estimated for 2017 (Table 3) from the available population data [23]. Therefore, basis on the Belo Horizonte and Betim population numbers in 2007 and adopting, respectively, annual growth rates of $1.16 \%$ and $4.54 \%$, with a spatial population distribution of $75 \%$ and $25 \%$, the sum-product value was calculated equal to $2.00 \%$. It was the adopted growth rate to determine the additional population inside the influenced area in 2017, which are 61,471 inhabitants.

The occupation of the influenced areas was calculated as follows: $51 \%\left(45.1 \mathrm{~km}^{2}\right)$ of its total surface were deducted, assumed as for the streets, wide open spaces and green areas; The remaining land, available for real estate, was classified as occupied areas (to improve and maintain), special areas and green areas; In addition, this occupation was decomposed by use in housing and commercial/services, according to the population's income patterns $\mathrm{A}, \mathrm{B}, \mathrm{C}$ and $\mathrm{D}$, and leisure areas.

\section{Potential Collection of the Tax on Real Estate Assets Due to the Improvements on Line 1}

The Tax on Real Estate Assets depends on the built occupied lands and their asset values. Two possible contexts were compared: with and without investments for the expansion and improvement of the line. For the purposes of this evaluation exercise, taking account of the difficulty to obtain and treat the actual and complete data in order to classify land use occupation by kind of occupation and kind of economic activities of the buildings in the area of influence of Line 1, some "reasonable" arbitrary values were assumed for the calculations:

- The percentage of land occupation in each property;

- The average number of floors of the buildings;

- The market values per $\mathrm{m}^{2}$ of real estate assets.

The former occupied and built surfaces were then determined as displayed in Tables 4-6. Those are the initial land occupation conditions of the "without investments" context.

For the "with investments" context, it was assumed that the same distribution of occupation patterns would have been kept, but there would be a built surface enhancement, calculated as the deduction of the total built surface of the "without investments" context from the total built surface of the "with investments" context, because of changes on the number of floors of the buildings. Tables 7-9 summarize these determinations.

The real estate's higher prices of the enhanced built surface were obtained from the multiplication of that surface by its asset value by the end of the analysis period. The recoverable amount of the Tax on Real Estate's Assets was deduced from such land price augmentation. Tables 10-13 present how were made the calculations.

\section{IPTU (Additional Urban Property Tax) Collection}

The additional urban property tax collection would depend on the enhanced built surfaces due to the expansion and improvement of Line 1 (differences

Table 2 Population and population density in the influenced area.

\begin{tabular}{|c|c|c|c|c|c|c|c|}
\hline Section & Start & End & Lenght (m) & Surface $\left(\mathrm{m}^{2}\right)$ & Population & $\begin{array}{l}\text { Density } \\
\text { (inhab./ha) }\end{array}$ & Remarks \\
\hline 1 & Novo Eldorado & $\begin{array}{l}\text { Nova } \\
\text { Rodoviária }\end{array}$ & 5,547 & $8,874,800$ & 23,247 & 26.2 & Half Betim + BH West \\
\hline 2 & Nova Rodoviária & Central & 5,519 & $8,830,000$ & 43,933 & 49.8 & Half BH West and BH Northwest \\
\hline 3 & Central & São Gabriel & 9,316 & $14,905,200$ & 134,484 & 90.2 & $\begin{array}{l}\text { BH Average (Center South + } \\
\text { Northeast + East) }\end{array}$ \\
\hline 4 & São Gabriel & Vilarinho & 7,819 & $12,510,000$ & 80,332 & 64.2 & Average of (Northeast + East) \\
\hline \multicolumn{3}{|c|}{ Totals and averages } & 28,200 & $45,120,000$ & 281,997 & 62.5 & \\
\hline
\end{tabular}


Table 3 Forecast of the population growth inside the influenced area in 2017.

\begin{tabular}{llllrl}
\hline Place & Population (2007) & Annual growth rate & Populations distribution & Population (2017) & Increment \\
\hline Belo Horizonte & $2,412,937$ & $1.16 \%$ & $75 \%$ & $2,707,701$ & 294,764 \\
Betim & 415,098 & $4.54 \%$ & $25 \%$ & 647,176 & 232,078 \\
Line 1 & 281,997 & $2.00 \%$ & - & 343,468 & 61,471 \\
\hline
\end{tabular}

Table 4 Percentage of land occupation patterns in the properties inside the influenced area by the Belo Horizonte's Metro Line1, in the "without investments" context.

\begin{tabular}{|c|c|c|c|c|}
\hline \multirow{2}{*}{ Land use } & \multicolumn{2}{|c|}{ Occupied areas } & \multirow{2}{*}{-Special areas } & \multirow{2}{*}{ Green areas } \\
\hline & To enhance & To maintain & & \\
\hline Housing & $65 \%$ & $65 \%$ & $10 \%$ & $60 \%$ \\
\hline Pattern A & $13.0 \%$ & $13.0 \%$ & $2.0 \%$ & $12.0 \%$ \\
\hline Pattern B & $26.0 \%$ & $26.0 \%$ & $4.0 \%$ & $24.0 \%$ \\
\hline Pattern C & $19.5 \%$ & $19.5 \%$ & $3.0 \%$ & $18.0 \%$ \\
\hline Pattern D & $6.5 \%$ & $6.5 \%$ & $1.0 \%$ & $6.0 \%$ \\
\hline Commercial/Services & $25 \%$ & $25 \%$ & $3 \%$ & $3 \%$ \\
\hline Pattern A & $5.0 \%$ & $5.0 \%$ & $0.6 \%$ & $0.6 \%$ \\
\hline Pattern B & $10.0 \%$ & $10.0 \%$ & $1.2 \%$ & $1.2 \%$ \\
\hline Pattern C & $7.5 \%$ & $7.5 \%$ & $0.9 \%$ & $0.9 \%$ \\
\hline Pattern D & $2.5 \%$ & $2.5 \%$ & $0.3 \%$ & $0.3 \%$ \\
\hline Leisure & $10 \%$ & $10 \%$ & $87 \%$ & $37 \%$ \\
\hline Total & $100 \%$ & $100 \%$ & $100 \%$ & $37 \%$ \\
\hline
\end{tabular}

Table 5 Average number of floors of the buildings inside the influenced area in the "without investments" context.

\begin{tabular}{lcccc}
\hline \multirow{2}{*}{ Land use } & \multicolumn{2}{c}{ Occupied areas } & Special areas & Green areas \\
\cline { 2 - 5 } & To enhance & To maintain & 0.01 \\
Housing & 1.50 & 1.20 & 0.01 & 0.01 \\
Pattern A & 1.30 & 1.50 & 0.01 & 0.01 \\
Pattern B & 1.20 & 1.40 & 0.01 & 0.01 \\
Pattern C & 0.95 & 0.85 & 0.01 & 0.01 \\
Pattern D & & & 0.01 & 0.01 \\
Commercial/Services & 1.15 & 1.30 & 0.01 & 0.01 \\
Pattern A & 1.15 & 1.30 & 0.01 & 0.01 \\
Pattern B & 1.15 & 1.30 & 0.01 & 0.01 \\
Pattern C & 1.15 & 1.30 & 0.01 & \\
Pattern D & 1.00 & 1.00 & & \\
Leisure & & & & \\
\hline
\end{tabular}

Table 6 Built surface of the properties inside the influenced area, in the "without investments" context, in $\mathrm{m}^{2}$.

\begin{tabular}{|c|c|c|c|c|}
\hline \multirow{2}{*}{ Land use } & \multicolumn{2}{|c|}{ Occupied areas } & \multirow{2}{*}{ Special areas } & \multirow{2}{*}{ Green areas } \\
\hline & To enhance & To maintain & & \\
\hline Housing & $2,692,310$ & $9,230,401$ & 1,624 & 4,873 \\
\hline Pattern A & 633,485 & $1,647,060$ & 325 & 975 \\
\hline Pattern B & $1,098,040$ & $4,117,651$ & 650 & 1,949 \\
\hline Pattern C & 760,182 & $2,882,356$ & 487 & 1,462 \\
\hline Pattern D & 200,604 & 583,334 & 162 & 487 \\
\hline Commercial/Services & 933,984 & $3,431,376$ & 487 & 244 \\
\hline Pattern A & 186,797 & 686,275 & 97 & 49 \\
\hline Pattern B & 373,594 & $1,372,550$ & 195 & 97 \\
\hline Pattern C & 280,195 & $1,029,413$ & 146 & 73 \\
\hline Pattern D & 93,398 & 343,138 & 49 & 24 \\
\hline Leisure & 324,864 & $1,055,808$ & 14,132 & 3,005 \\
\hline Total & $3,951,158$ & $13,717,585$ & 16,243 & 8,122 \\
\hline
\end{tabular}

Values obtained by the multiplication of the total surface of the properties by the Table 4 percentages and by the numbers of floors taken from Table 5 , deduced of $25 \%$, due to legal limitations of the built surface due to the number of floors, according to the authors' estimations. 
Table 7 Average number of floors of the buildings inside the influenced area, in the "with investments" context.

\begin{tabular}{|c|c|c|c|c|}
\hline \multirow{2}{*}{ Land use } & \multicolumn{2}{|c|}{ Occupied areas } & \multirow{2}{*}{-Special areas } & \multirow{2}{*}{ Green areas } \\
\hline & To enhance & To maintain & & \\
\hline \multicolumn{5}{|l|}{ Housing } \\
\hline Pattern A & 3.00 & 1.22 & 0.01 & 0.01 \\
\hline Pattern B & 2.60 & 1.53 & 0.01 & 0.01 \\
\hline Pattern C & 2.22 & 1.43 & 0.01 & 0.01 \\
\hline Pattern D & 1.76 & 0.87 & 0.01 & 0.01 \\
\hline \multicolumn{5}{|c|}{ Commercial/Services } \\
\hline Pattern A & 2.30 & 1.33 & 0.01 & 0.01 \\
\hline Pattern B & 2.30 & 1.33 & 0.01 & 0.01 \\
\hline Pattern C & 2.13 & 1.33 & 0.01 & 0.01 \\
\hline Pattern D & 2.13 & 1.33 & 0.01 & 0.01 \\
\hline Leisure & 1.50 & 1.02 & 1.00 & 1.00 \\
\hline
\end{tabular}

Values proposed by the authors.

between built surfaces of the "with" and "without investments", as shown in Table 9). For this exercise's purposes, the usual charged rates $(0.80 \%$ of the market price for housing and $1.60 \%$ for the commercial and service ones, respectively), were reduced to $0.29 \%$ and $0.76 \%$ in order to simulate the effect of some aspects such as the underestimation of the market value of the property, the under-reporting of this value and the reduction due to the time of use (the building's age). The results of this calculation are shown in Table 14.

Additionally, the authors proposed that the allocated share to cover the investment costs would be limited to $30 \%$ from the total property tax collection due to the expansion and improvement of Line 1, reaching $R \$ 6,533,560.57$.

\section{ICMS (Additional Collection of the Added Value on Goods and Services Tax) and ISS (of the Services Tax) Due to the Construction Activities in the Properties}

The ICMS (additional added value on goods and services tax) income due to the construction works to the enhanced built surfaces inside the influenced area of the Belo Horizonte's Metro Line 1 was assumed to be charged on the construction materials acquisition costs, while the ISS (services tax) would be related to the whole construction costs. The materials cost estimate was assumed to be equal to $40 \%$ of the construction costs. The construction costs were assumed to be the remainder of the deduction of the real estate profits and the cleared land costs from the real estate profits due to the increased built surfaces (Table 11 values). The cleared land cost was assumed to be equal to $15 \%$ of total construction costs (labor + cleared land acquisition costs).

It was also assumed that $60 \%$ of the construction materials would be purchased in the state of Minas Gerais, where the average ICMS rate is $16 \%$. The remaining $40 \%$ would come from other states, whose rates were assumed to be around $8 \%$. It was still assumed that the ICMS collection share between the state's Government and the municipalities is $75 \%$ and 25\%, respectively, and Belo Horizonte and Betim are provided with $12.4 \%$ and $2.0 \%$ of the municipalities' share, the corresponding percentages for their respective populations and the state's population.

The same underestimations of property market values and of their under-reporting assumptions (displayed on Table 11) were applied to the ICMS and ISS collection estimations.

Finally, it was also assumed that the recoverable part of the investments on Line 1 would be $40 \%$ of the total collected taxes inside its influenced area. 
Table 8 Built surface of the properties inside the influenced area, in the "with investments" context, in $\mathbf{m}^{2}$.

\begin{tabular}{|c|c|c|c|c|}
\hline \multirow{2}{*}{ Land use } & \multicolumn{2}{|c|}{ Occupied areas } & \multirow{2}{*}{ Special areas } & \multirow{2}{*}{ Green areas } \\
\hline & To enhance & To maintain & & \\
\hline Housing & $5,240,503$ & $9,415,009$ & 1,626 & 4,878 \\
\hline Pattern A & $1,266,970$ & $1,680,002$ & 325 & 976 \\
\hline Pattern B & $2,196,081$ & $4,200,004$ & 650 & 1,951 \\
\hline Pattern C & $1,406,336$ & $2,940,003$ & 488 & 1,463 \\
\hline Pattern D & 371,117 & 595,001 & 163 & 488 \\
\hline Commercial/Services & $1,811,929$ & $3,500,004$ & 488 & 244 \\
\hline Pattern A & 373,594 & 700,001 & 98 & 49 \\
\hline Pattern B & 747,187 & $1,400,001$ & 195 & 98 \\
\hline Pattern C & 518,361 & $1,050,001$ & 146 & 73 \\
\hline Pattern D & 172,787 & 350,000 & 49 & 24 \\
\hline Leisure & 487,296 & $1,076,924$ & 14,132 & 3,005 \\
\hline Total & $7,539,728$ & $13,991,937$ & 16,245 & 8,127 \\
\hline
\end{tabular}

Values obtained by the multiplication of the total surface of the properties by the Table 4 percentages and by the numbers of floors taken from Table 7 , deduced of $25 \%$, due to legal limitations of the built surface because of the number of floors, according to the authors' estimate.

Table 9 Enhanced built surface of the properties inside the influenced area, in the "with investments" context, in $\mathrm{m}^{2}$.

\begin{tabular}{|c|c|c|c|c|}
\hline \multirow{2}{*}{ Land use } & \multicolumn{2}{|c|}{ Occupied areas } & \multirow{2}{*}{ Special areas } & \multirow{2}{*}{ Green areas } \\
\hline & To enhance & To maintain & & \\
\hline Housing & $2,548,193$ & 184,608 & 2 & 5 \\
\hline Pattern A & 633,485 & 32,941 & 0 & 1 \\
\hline Pattern B & $1,098,040$ & 82,353 & 1 & 2 \\
\hline Pattern C & 646,154 & 57,647 & 0 & 1 \\
\hline Pattern D & 170,513 & 11,667 & 0 & 0 \\
\hline Commercial/Services & 877,945 & 68,628 & 0 & 0 \\
\hline Pattern A & 186,797 & 13,726 & 0 & 0 \\
\hline Pattern B & 373,594 & 27,451 & 0 & 0 \\
\hline Pattern C & 238,166 & 20,588 & 0 & 0 \\
\hline Pattern D & 79,389 & 6,863 & 0 & 0 \\
\hline Leisure & 162,432 & 21,116 & - & - \\
\hline Total & $3,588,570$ & 274,352 & 2 & 5 \\
\hline
\end{tabular}

Values obtained by deduction of the Table 6 values from those of Table 8.

Table 10 Average real state's market prices inside the influenced area, in the "with investments" context.

\begin{tabular}{|c|c|c|c|c|}
\hline \multirow[b]{2}{*}{ Land use } & \multicolumn{4}{|c|}{ Average prices $\left(\mathrm{R} \$ / \mathrm{m}^{2}\right)$} \\
\hline & To enhance & $\begin{array}{l}\text { Occupied area } \\
\text { To maintain }\end{array}$ & Special areas & Green areas \\
\hline \multicolumn{5}{|l|}{ Housing } \\
\hline Pattern A & 1,440 & 1,440 & 1,440 & 1,440 \\
\hline Pattern B & 960 & 960 & 960 & 960 \\
\hline Pattern C & 600 & 600 & 600 & 600 \\
\hline Pattern D & 240 & 240 & 240 & 240 \\
\hline \multicolumn{5}{|c|}{ Commercial/Services } \\
\hline Pattern A & 3,000 & 3,000 & 3,000 & 3,000 \\
\hline Pattern B & 1,800 & 1,800 & 1,800 & 1,800 \\
\hline Pattern C & 1,200 & 1,200 & 1,200 & 1,200 \\
\hline Pattern D & 600 & 600 & 600 & 600 \\
\hline Leisure & 1,200 & 1,200 & 1,200 & 1,200 \\
\hline
\end{tabular}

Values proposed by the authors. 
Table 11 Market prices of the enhanced built surface of the properties inside the influenced area, in the "with investments" context.

\begin{tabular}{|c|c|c|c|c|c|}
\hline \multirow{3}{*}{ Land use } & \multicolumn{5}{|c|}{ Land assets market prices $(\mathrm{R} \$ 1,000)$} \\
\hline & \multicolumn{2}{|c|}{ Occupied areas } & \multirow{2}{*}{ Special areas } & \multirow{2}{*}{ Green areas } & \multirow{2}{*}{ Total } \\
\hline & To enhance & To maintain & & & \\
\hline Housing & $2,394,953$ & 163,883 & 1 & 4 & $2,558,841$ \\
\hline Pattern A & 912,218 & 47,435 & 0 & 1 & 959,655 \\
\hline Pattern B & $1,054,119$ & 79,059 & 1 & 2 & $1,133,180$ \\
\hline Pattern C & 387,693 & 34,588 & 0 & 1 & 422,282 \\
\hline Pattern D & 40,923 & 2,800 & 0 & 0 & 43,723 \\
\hline Commercial/Services & $1,566,291$ & 119,412 & 1 & 0 & $1,685,704$ \\
\hline Pattern THE & 560,390 & 41,177 & 0 & 0 & 601,567 \\
\hline Pattern B & 672,468 & 49,412 & 0 & 0 & 721,881 \\
\hline Pattern C & 285,799 & 24,706 & 0 & 0 & 310,505 \\
\hline Pattern D & 47,633 & 4,118 & 0 & 0 & 51,751 \\
\hline Leisure & 194,918 & 25,339 & - & - & 220,258 \\
\hline Total & $4,156,162$ & 308,634 & 2 & 5 & $4,464,803$ \\
\hline
\end{tabular}

Values calculated by multiplication of Table 9 and Table 10 values.

Table 12 Rates for the Tax on Real Estate Assets collection.

\begin{tabular}{|c|c|c|c|c|}
\hline \multirow{3}{*}{ Land use } & \multicolumn{4}{|c|}{ Rate } \\
\hline & \multicolumn{2}{|c|}{ Occupied areas } & \multirow{2}{*}{ Special areas } & \multirow{2}{*}{ Green areas } \\
\hline & To enhance & To maintain & & \\
\hline \multicolumn{5}{|l|}{ Housing } \\
\hline Pattern A & $10 \%$ & $10 \%$ & $10 \%$ & $10 \%$ \\
\hline Pattern B & $8 \%$ & $8 \%$ & $8 \%$ & $8 \%$ \\
\hline Pattern C & $2 \%$ & $2 \%$ & $2 \%$ & $2 \%$ \\
\hline Pattern D & $0 \%$ & $0 \%$ & $0 \%$ & $0 \%$ \\
\hline \multicolumn{5}{|c|}{ Commercial/Services } \\
\hline Pattern A & $15 \%$ & $15 \%$ & $15 \%$ & $15 \%$ \\
\hline Pattern B & $10 \%$ & $8 \%$ & $8 \%$ & $8 \%$ \\
\hline Pattern C & $6 \%$ & $6 \%$ & $6 \%$ & $6 \%$ \\
\hline Pattern D & $0 \%$ & $0 \%$ & $0 \%$ & $0 \%$ \\
\hline Leisure & $10 \%$ & $10 \%$ & $10 \%$ & $10 \%$ \\
\hline
\end{tabular}

Table 13 Recoverable collection of the Tax on Real Estate Assets due to the enhanced built surfaces of the properties inside the influenced area in the "with investments" context.

\begin{tabular}{|c|c|c|c|c|c|}
\hline \multirow{3}{*}{ Land use } & \multicolumn{5}{|c|}{ Recoverable collection $(\mathrm{R} \$ 1,000)$} \\
\hline & \multicolumn{2}{|c|}{ Occupied areas } & \multirow{2}{*}{ Special areas } & \multirow{2}{*}{ Green areas } & \multirow{2}{*}{ Total } \\
\hline & To enhance & To maintain & & & \\
\hline Housing & 80,116 & 5,114 & 0 & 0 & 85,230 \\
\hline Pattern A & 41,050 & 2,135 & 0 & 0 & 43,184 \\
\hline Pattern B & 35,577 & 2,668 & 0 & 0 & 38,245 \\
\hline Pattern C & 3,489 & 311 & 0 & 0 & 3,801 \\
\hline Pattern D & - & - & - & - & - \\
\hline Commercial/Services & 88,438 & 6,096 & 0 & 0 & 94,534 \\
\hline Pattern A & 44,131 & 3,243 & 0 & 0 & 47,373 \\
\hline Pattern B & 35,305 & 2,075 & 0 & 0 & 37,380 \\
\hline Pattern C & 9,003 & 778 & 0 & 0 & 9,781 \\
\hline Pattern D & - & - & - & - & - \\
\hline Leisure & 10,233 & 1,330 & - & - & 11,564 \\
\hline Total & 178,787 & 12,541 & 0 & 0 & 191,328 \\
\hline
\end{tabular}

The rates were reduced to $45 \%$ and $52.5 \%$ of the Table 11 values, respectively for the Habitational uses and Commercial/Services, as an authors' assumption for the underestimation of the real estate's market prices and the under-reporting of the real estate assets values. 
Table 14 IPTU collection due to the enhanced built surfaces of the properties inside the influenced area.

\begin{tabular}{|c|c|c|c|c|c|}
\hline \multirow{3}{*}{ Land use } & \multicolumn{5}{|c|}{ IPTU collection (R\$) } \\
\hline & \multicolumn{2}{|c|}{ Occupied areas } & \multirow{2}{*}{ Special areas } & \multirow{2}{*}{ Green areas } & \multirow{2}{*}{ Total } \\
\hline & To enhance & To maintain & & & \\
\hline Housing & $6,897,464$ & 471,982 & 4 & 12 & $7,369,462$ \\
\hline Pattern A & $2,627,188$ & 136,614 & 1 & 4 & $2,763,807$ \\
\hline Pattern B & $3,035,862$ & 227,690 & 2 & 5 & $3,263,559$ \\
\hline Pattern C & $1,116,555$ & 99,614 & 1 & 3 & $1,216,173$ \\
\hline Pattern D & 117,859 & 8,064 & 0 & 0 & 125,923 \\
\hline Commercial/Services & $11,841,161$ & 902,754 & 6 & 3 & $12,743,925$ \\
\hline Pattern A & $4,236,551$ & 311,294 & 2 & 1 & $4,547,849$ \\
\hline Pattern B & $5,083,862$ & 373,553 & 3 & 1 & $5,457,419$ \\
\hline Pattern C & $2,160,641$ & 186,777 & 1 & 1 & $2,347,420$ \\
\hline Pattern D & 360,107 & 31,129 & 0 & 0 & 391,237 \\
\hline Leisure & $1,473,583$ & 191,566 & - & - & $1,665,149$ \\
\hline Total & $20,212,208$ & $1,566,301$ & 11 & 15 & $21,778,535$ \\
\hline
\end{tabular}

The ICMS (additional added value tax on goods and services) and ISSQN (tax services of any nature) collection due to construction activities in the private properties inside the influenced area were supposed to be a function of the real estate assets profits resulting from those constructions. Calculation of this value is displayed on Table 15.

\section{ISSQN (Additional Collection of the Tax on Services of Any Nature) Due to the Generation of Services Activities in the Enhanced Built Surfaces}

The income from the additional ISSQN collection due the generated services activities inside the enhanced built surfaces of the influenced area of the Belo Horizonte's Metro Line 1 was assumed as a function of the real estate's market prices of the Commercial, Services and leisure properties where built surfaces have increased due to Line 1 investments and expansion. An estimation of this function was provided by the result of the division of the total collected ISSQN's amount inside the influenced area in 2007, by the real estate market prices in the same year. The calculation details are in Table 16.
8. Financial Cashflow Analysis of the Recovered Taxes Collected Income Due to the Investments on the Expansion and Improvement of the Belo Horizonte's Metro Line 1

A cash flow has been prepared in order to estimate the whole amount of recoverable tax collection by Line 1 improvement and expansion. Firstly, the annual installments were assumed as a linear distribution of the total real estate's rising prices rate percentage over the considered time period (in current values).

$$
p_{n}=\frac{V C_{N} \times n}{\sum_{n=1}^{N} n}
$$

where,

$$
\begin{aligned}
& p_{n}=\text { installment of year } \mathrm{n} ; \\
& V C_{N}=\text { total current value of period } \mathrm{N} ; \\
& N=10 \text { years. }
\end{aligned}
$$

Cash flow present values were set with an $11.64 \%$ annual discount rate (reference rate practiced by BNDES in project financing), during a 10 years Table 17 displays the current values recoverable taxes cash flows, their present values and the net total present value. 
Table 15 Determination of the recoverable ICMS and ISS collection due to the construction works of the enhanced built surfaces inside the influenced area of the Belo Horizonte's Metro Line 1.

(a) Assumed real estate assets prices for fiscal purposes.

\begin{tabular}{|c|c|c|c|c|c|}
\hline \multirow[b]{2}{*}{ Land use } & \multicolumn{3}{|c|}{ Tax collection reduction rates due to } & \multirow[b]{2}{*}{$\begin{array}{l}\text { - Reduction } \\
\text { factor }\end{array}$} & \multirow{2}{*}{$\begin{array}{l}\text { Assets prices for fiscal } \\
\text { purposes }(\mathrm{R} \$ 1,000)\end{array}$} \\
\hline & $\begin{array}{l}\text { Real estate's market } \\
\text { prices }(\mathrm{R} \$ 1,000)^{\mathrm{a}}\end{array}$ & $\begin{array}{l}\text { Underestimation } \\
\text { of market prices }{ }^{\mathrm{b}}\end{array}$ & Under-reporting $^{\mathrm{b}}$ & & \\
\hline Housing & $2,558,841$ & $75 \%$ & $40 \%$ & $45.0 \%$ & $1,151,478$ \\
\hline Commercial, services and leisure & $1,905,962$ & $75 \%$ & $30 \%$ & $52.5 \%$ & $1,000,630$ \\
\hline Total & & & & & $2,152,108$ \\
\hline \multicolumn{6}{|c|}{$\begin{array}{l}\text { a According to calculations in Table } 11 . \\
\text { b Estimations by the authors. }\end{array}$} \\
\hline \multicolumn{3}{|c|}{ Composition of the real estate's assets prices for fiscal purposes } & Percentage $^{\mathrm{a}}$ & \multicolumn{2}{|r|}{ Share $(\mathrm{R} \$ 1,000)$} \\
\hline Total assets prices & & & & \multicolumn{2}{|c|}{$2,152,108$} \\
\hline \multicolumn{3}{|c|}{ Profits from the construction activities } & $40 \%$ & \multicolumn{2}{|r|}{860,843} \\
\hline \multicolumn{3}{|c|}{ Cleared land prices + Construction works costs } & & \multicolumn{2}{|c|}{$1,291,265$} \\
\hline \multicolumn{3}{|l|}{ Cleared land prices } & $15 \%$ & \multicolumn{2}{|r|}{193,690} \\
\hline \multicolumn{3}{|l|}{ Construction works cost } & & \multicolumn{2}{|c|}{$1,097,575$} \\
\hline \multicolumn{3}{|l|}{ Labor force } & $40 \%$ & \multicolumn{2}{|r|}{439,030} \\
\hline \multicolumn{3}{|l|}{ Construction materials } & & \multicolumn{2}{|r|}{658,545} \\
\hline
\end{tabular}

${ }^{a}$ Values proposed by the authors.

(b) ICMS collection due to Line 1 improvement and expansion.

\begin{tabular}{|c|c|c|c|c|}
\hline \multirow[b]{2}{*}{ Tax collection sources } & \multicolumn{2}{|c|}{ Collection tax share by source } & \multirow{2}{*}{$\begin{array}{l}\text { Tax collection } \\
\text { rates }^{\text {a }}\end{array}$} & \multirow[b]{2}{*}{$\begin{array}{l}\text { Fiscal income } \\
(\mathrm{R} \$ 1,000)\end{array}$} \\
\hline & Share rate ${ }^{\mathrm{a}}$ & $\begin{array}{l}\text { Shared amount } \\
(\mathrm{R} \$ 1,000)\end{array}$ & & \\
\hline Construction materials purchased outside the state of Minas Gerais & $40 \%$ & 263,418 & $8 \%$ & 21,073 \\
\hline Construction materials purchased within the state of Minas Gerais & $60 \%$ & 395,127 & $16 \%$ & 63,220 \\
\hline Total & & 658,545 & & 84,294 \\
\hline
\end{tabular}

${ }^{\mathrm{a}}$ Values proposed by the authors.

\begin{tabular}{lcc}
\hline Beneficiaries from ICMS collection & Collection income share ${ }^{\mathrm{a}}$ & Shared income (R\$ 1,000) $^{\circ}$ \\
\hline State’s Government & $75 \%$ & 63,220 \\
Municipalities & $25 \%$ & 21,073 \\
Belo Horizonte & $12.4 \%$ & 2,603 \\
Betim & $2.0 \%$ & 427 \\
\hline
\end{tabular}

Shared ICMS fiscal income by the state of Minas Gerais, Belo Horizonte and Betim (R\$ 1,000) 66,250

$\begin{array}{ll}\text { ICMS collection percentage to cover Line } 1 \text { investments }{ }^{\text {a }} & 40 \%\end{array}$

$\begin{array}{lr}\text { ICMS collected amount to cover Line } 1 \text { investments (R\$ 1,000) } & 26,500\end{array}$

${ }^{a}$ Values proposed by the authors.

(c) ISS collection due to Line 1 improvement and expansion.

\begin{tabular}{ll}
\hline Construction works cost (R\$ 1,000) & $1,097,575$ \\
ISS rate collected from construction activities & $5 \%$ \\
ISS collection from construction activities (R \$ 1,000) & 54,879 \\
ISS collection percentage to cover Line 1 investments ${ }^{\text {a }}$ & $40 \%$ \\
\hline ISS collected amount to cover Line 1 investments $(\mathrm{R} \$ 1,000)$ & \\
\hline
\end{tabular}

\footnotetext{
${ }^{\mathrm{a}}$ Values proposed by the authors.
} 
(d) Summary of fiscal income from ICMS and ISS collection to cover the investments for the expansion and improvement on Belo Horizonte's Metro Line 1.

\begin{tabular}{ll}
\hline Fiscal source & Recoverable amount $(\mathrm{R} \$)$ \\
\hline ICMS & $26,500,164$ \\
ISS & $21,951,507$ \\
ICMS and ISS & $48,451,671$ \\
\hline
\end{tabular}

Table 16 Determination of the recoverable ISSQN collection due to the generation of services activities inside the influenced area of the Belo Horizonte's Metro Line 1.

(a) Average real estate's market prices inside the influenced area, in the "with investments" context.

\begin{tabular}{|c|c|c|c|c|}
\hline \multirow{3}{*}{ Land use } & \multicolumn{4}{|c|}{ Average prices $\left(\mathrm{R} \$ / \mathrm{m}^{2}\right)$} \\
\hline & \multicolumn{2}{|c|}{ Occupied areas } & \multirow{2}{*}{ Special areas } & \multirow{2}{*}{ Green areas } \\
\hline & To enhance & To maintain & & \\
\hline \multicolumn{5}{|l|}{ Housing } \\
\hline Pattern A & 1,200 & 1,200 & 1,200 & 1,200 \\
\hline Pattern B & 800 & 800 & 800 & 800 \\
\hline Pattern C & 500 & 500 & 500 & 500 \\
\hline Pattern D & 200 & 200 & 200 & 200 \\
\hline \multicolumn{5}{|c|}{ Commercial/Services } \\
\hline Pattern A & 2,500 & 2,500 & 2,500 & 2,500 \\
\hline Pattern B & 1,500 & 1,500 & 1,500 & 1,500 \\
\hline Pattern C & 1,000 & 1,000 & 1,000 & 1,000 \\
\hline Pattern D & 500 & 500 & 500 & 500 \\
\hline Leisure & 1,000 & 1,000 & 1,000 & 1,000 \\
\hline
\end{tabular}

Values obtained by the reduction of a supposed 20\% profit during the considered period of analysis from the Table 10 values.

(b) Real estate market prices of the properties inside the influenced area by the Belo Horizonte's Metro Line1, in the "without investments" context in 2007.

\begin{tabular}{|c|c|c|c|c|}
\hline \multirow{3}{*}{ Land use } & \multicolumn{4}{|c|}{ Real estate prices (R\$1000) } \\
\hline & \multicolumn{2}{|c|}{ Occupied areas } & \multirow{2}{*}{-Special areas } & \multirow{2}{*}{ Green areas } \\
\hline & To enhance & To maintain & & \\
\hline Housing & $2,058,826$ & $6,828,438$ & 1,186 & 3,557 \\
\hline Pattern A & 760,182 & $1,976,473$ & 390 & 1,170 \\
\hline Pattern B & 878,432 & $3,294,121$ & 520 & 1,559 \\
\hline Pattern C & 380,091 & $1,441,178$ & 244 & 731 \\
\hline Pattern D & 40,121 & 116,667 & 32 & 97 \\
\hline Commercial/Services & $1,354,277$ & $4,975,495$ & 707 & 353 \\
\hline Pattern A & 466,992 & $1,715,688$ & 244 & 122 \\
\hline Pattern B & 560,390 & $2,058,826$ & 292 & 146 \\
\hline Pattern C & 280,195 & $1,029,413$ & 146 & 73 \\
\hline Pattern D & 46,699 & 171,569 & 24 & 12 \\
\hline Leisure & 324,864 & $1,055,808$ & 14,132 & 3,005 \\
\hline Total & $3,737,966$ & $12,859,741$ & 16,024 & 6,916 \\
\hline
\end{tabular}

Values obtained from the multiplication of the existing built surfaces in 2007 (Table 6) by the average real estate’s market prices from Table 16a. 
(c) IPTU's total collection estimates due to existing properties inside the influenced area in 2007, in the "without investments" context.

\begin{tabular}{|c|c|c|c|c|c|}
\hline \multirow{3}{*}{ Land use } & \multicolumn{5}{|c|}{ Annual IPTU’s collection (R\$ 1,000) } \\
\hline & \multicolumn{2}{|c|}{ Occupied areas } & \multirow{2}{*}{-Special areas } & \multirow{2}{*}{ Green areas } & \multirow{2}{*}{ Total } \\
\hline & To enhance & To maintain & & & \\
\hline Housing & 5,929 & 19,666 & 3 & 10 & 25,609 \\
\hline Pattern A & 2,189 & 5,692 & 1 & 3 & 7,886 \\
\hline Pattern B & 2,530 & 9,487 & 1 & 4 & 12,023 \\
\hline Pattern C & 1,095 & 4,151 & 1 & 2 & 5,248 \\
\hline Pattern D & 116 & 336 & 0 & 0 & 452 \\
\hline Commercial/Services & 10,238 & 37,615 & 5 & 3 & 47,861 \\
\hline Pattern A & 3,530 & 12,971 & 2 & 1 & 16,504 \\
\hline Pattern B & 4,237 & 15,565 & 2 & 1 & 19,805 \\
\hline Pattern C & 2,118 & 7,782 & 1 & 1 & 9,902 \\
\hline Pattern D & 353 & 1,297 & 0 & 0 & 1,650 \\
\hline Leisure & 2,456 & 7,982 & 107 & 23 & 10,567 \\
\hline Housing & 18,624 & 65,263 & 116 & 36 & 84,038 \\
\hline
\end{tabular}

Values obtained from the multiplication of the Table $16 \mathrm{~b}$ values by the factors of $0.29 \%$ for housing, and $0.76 \%$ for the commercial, services and leisure properties, as described for the tax on real estate assets evaluation.

(d) ISSQN's total collection estimates due to the generation of services activities inside the influenced area in 2007, in the "without investments context”.

Determination of the percentage of the Belo Horizonte's IPTU's estimated collected total amount due to the properties inside the influenced area

IPTU's collected amount inside the influenced area in 2007 (R\$)

$84,037,502$

Total IPTU's collected amount in Belo Horizonte in $2007(\mathrm{R} \$)^{\mathrm{a}}$

$691,859,577$

Percentage of total IPTU's collection due to the properties inside the influenced area in 2007

$12.1 \%$

${ }^{a}$ Estimated amount by extrapolation from the actual collected amount in 2005.

Estimation of ISSQN's annual collection inside the influenced area

ISSQN's total collected amount in Belo Horizonte in 2007 (R\$) ${ }^{\text {a }}$

$463,936,000$

Estimated percentage of ISSQN's collected amount inside the influenced area in $2007^{\mathrm{b}}$

$9.3 \%$

ISSQN's estimated collected amount inside the influenced area in 2007 (R\$)

$43,348,083$

${ }^{\mathrm{a}}$ Values from Table 16b.

${ }^{\mathrm{b}}$ Values from Table 11.

(e) Determination of the recoverable ISSQN collection due to the generation of services activities in the enhanced built surfaces of the properties used for commercial, services and leisure purposes inside the influenced area.

\begin{tabular}{lll}
\hline Topic & Unit & Value \\
\hline ISSQN's estimated collected amount inside the influenced area in 2007 (R\$) & $\mathrm{R} \$$ & $43,348,083$ \\
Former real estate market prices in 2007, in the “without investments” context ${ }^{\text {a }}$ & $\mathrm{R} \$$ & $7,728,640,445$ \\
ISSQN's estimated collection / real estate market prices & $\mathrm{R} \$ \mathrm{R} \$$ & 0.00561 \\
Assumed ratio for the exercise's purposes & & $0.50 \%$ \\
Real estate market prices of the enhanced built surfaces due to the investments on Line 1 & $\mathrm{R} \$ 1,000$ & $1,905,962.12$ \\
Annual ISSQN collected additional amount due to the investments & $\mathrm{R} \$$ & $9,529,810.58$ \\
\hline
\end{tabular}

\footnotetext{
${ }^{a}$ Values from Table $16 b$.
}

${ }^{\mathrm{b}}$ Values from Table 11. 
Table 17 Present values of the recoverable taxes due to the expansion and improvement of the Belo Horizonte Metro's Line 1.

\begin{tabular}{|c|c|c|c|c|c|c|c|c|c|c|c|c|}
\hline \multirow{3}{*}{ Recoverable taxes } & \multirow{3}{*}{ Present values } & \multicolumn{11}{|c|}{ Current values (R\$106) } \\
\hline & & \multirow{2}{*}{ Total } & \multicolumn{10}{|c|}{ Year } \\
\hline & & & 2007 & 2008 & 2009 & 2010 & 2011 & 2012 & 2013 & 2014 & 2015 & 2016 \\
\hline Tax on Real Estate Assets & 102.7 & 191.3 & 3.5 & 7.0 & 10.4 & 13.9 & 17.4 & 20.9 & 24.4 & 27.8 & 31.3 & 34.8 \\
\hline IPTU & 3.5 & 6.5 & 0.1 & 0.2 & 0.4 & 0.5 & 0.6 & 0.7 & 0.8 & 1.0 & 1.1 & 1.2 \\
\hline ICMS + ISS & 26.0 & 48.5 & 0.9 & 1.8 & 2.6 & 3.5 & 4.4 & 5.3 & 6.2 & 7.0 & 7.9 & 8.8 \\
\hline ISSQN & 5.1 & 9.5 & 0.2 & 0.3 & 0.5 & 0.7 & 0.9 & 1.0 & 1.2 & 1.4 & 1.6 & 1.7 \\
\hline Total & 137.3 & 255.8 & 4.7 & 9.3 & 14.0 & 18.6 & 23.3 & 27.9 & 32.6 & 37.2 & 41.9 & 46.5 \\
\hline
\end{tabular}

\section{Conclusions}

This work presents an estimation of value capture as a strategy to be explored to expand the potential resources to finance public transport infrastructure. In that sense, the capitalization of the financial benefit, specifically its recoverable share by the government, would be a more consistent way for such financing. It opposes the real estate's expansion and higher prices inside the infrastructure influenced area to tax payers' collective charges, even if they would be, directly or indirectly, their beneficiaries. In particular, assuming the very likely hypothesis that it would be up to the Government carry out the infrastructure's implantation capital expenditures, the central question to be studied was the evaluation of how much the bigger tax collected amount, exclusively due to the financial benefits, could recover a part of the spent public resources.

The viability of the fiscal capture of the real estate market's growth was simulated for the Belo Horizonte Metro's Line 1, starting from the concept of value capture from the benefit due to its expansion and improvement, as base as a basis for obtaining resources for the infrastructure's implementation and operation.

More specifically, the following revenues were analyzed: (1) the potential recovery of the collection of a tax on real estate assets inside the Line 1 influenced area; (2) the additional Urban Property Tax collection corresponding to the enhanced built surfaces inside the influenced area; (3) the ICMS (Circulation of Goods and Services Tax) and the ISS (Service Tax) collection corresponding to the construction activities in the enhanced built surfaces of the influenced area; (4) the ISSQN on behalf of the generated service activities in the enhanced built surfaces of the influenced area.

The foreseen investments on Line 1 were fleet acquisition, signaling system, maintenance equipments, systems and equipment, technical assistance, studies and projects, construction/ rehabilitation of stations, construction of a new Bus Station and of the expressway to the new State's Government's Administrative Center. The total expenditure will be around R\$ 326.7 million. The exercise's simulations show, in conservative way, that it would be possible to recover a significant portion such total expenditure, about R\$137.3 million, $42 \%$ of the total.

The first main share, about $75 \%$ of the recoverable amount, would be provided by the potential collection of the tax on real estate's assets. It is a proof of the value capture moral basis: the unequivocal real estate's higher market prices of some beneficiary properties.

The other main share, about $19 \%$ of the total amount, comes from the recoverable ICMS and ISS collected share concerning the construction activities to enhance the built surfaces. Finally, the property tax and ISSQN share is approximately $7 \%$ of the captured value.

Financing public transport infrastructures as metro lines by means of the value capture provided by its implementations is also a regulatory and urban management tool, because it can be used to control the infrastructure's impacts on the real estate's market prices. 


\section{References}

[1] J. Barat, The Evolution of Transportation in Brazil, Brazilian Institute of Geography and Statistics/Institute of Economic and Social Planning, Rio de Janeiro, 1978, p. 385. (in Portuguese)

[2] J.J.G. Aragão, Principles for Territorial Engineering, Discussion Paper No. 2, CEFTRU/UNB-Center for Human Resources Training in Transportation, Brasília, 2008. (in Portuguese)

[3] D. Aschauer, Is public expenditure productive?, Journal of Monetary Economics 23 (1989) 177-200.

[4] The World Bank, World Development Report 1994, Infrastructure for Development, Washington, 1994.

[5] W. Lu, Public Infrastructure and Regional Economic Development: Evidence from China, Pacific Economic Paper 258, The Australian National University, Canberra, 1996.

[6] D. Banister, Y. Berechman, Transport investment and the promotion of economic growth, Journal of Transport Geography 9 (3) (2001) 209-218.

[7] OCDE-Organization for Economic Co-operation and Development, Impact of Transport Infrastructure Investment on Regional Development, Paris, 2003.

[8] A. Estache, M. Fay, Current Debates on Infrastructure Policy, Policy Research Working Paper 4410, The World Bank, Washington, 2007.

[9] F.J. Rigolon, M.S. Piccinini, The Infrastructure Investment and Resumption of Sustained Economic Growth, Sector Discussion Paper No. 63, BNDES, Rio de Janeiro, 1997. (in Portuguese)

[10] P.C. Ferreira, T.G. Milliagros, Impacts on productive infrastructure in Brazil, 1950/95, Research and Economic Planning 28 (2) (1998) 315-338. (in Portuguese)

[11] R.M. Benitez, Infrastructure, its relationship to total factor productivity and its effects on regional product, Planning and PPP (Public Policy Review) 19 (1999) 275-306. (in Portuguese)

[12] J.O. Cândido, Public spending in Brazil is productive?, Planning and Public Policy Review 23 (2001) 233-260. (in Portuguese)

[13] F. Rocha, A.C. Giuberti, Composition of Public Expenditure and Economic Growth: A Panel Study for Brazilian States, 2006, http://www.anpec. org.br/encontro2005/artigos/A05A049.pdf (accessed Aug. 9, 2006). (in Portuguese)
[14] A. Pedler, A Transport Planners' Guide to Capturing Land Value Uplift, Transport Planning Society, 2003, http://www.tps.org.uk/activities/bursaries/bursary2003.ht m (accessed Jan. 1, 2012).

[15] H. Dittmar, G. Ohland, The New Transit Town, Best Practices in Transit-Oriented Development, Island Press, Washington, 2004.

[16] D. Belzer, G. Autler, Transit Oriented Development: Moving from Rethoric to Reality, Discussion Paper, The Brookings Institution Center on Urban and Metropolitan Policy, Washington, 2002.

[17] R. Cervero, C. Ferrell, S. Murphy, Transit-Oriented Development and Joint Development in the United States, A Literature Review Research Results Digest 52, Transportation Research Board, Washington, Oct. 2002.

[18] R. Cervero, S. Murphy, C. Ferrel, N Goguts, Y.H Tsai, Transit Oriented Development in the United States: Experiences, Challenges and Prospects, TCRP Report 102, Transportation Research Board, Washington, 2004.

[19] J.J. Smith, T.A. Gihring, Financing transit systems through value capture: An annotated bibliography, The American Journal of Economics and Sociology 65 (3) (2006) 751-786.

[20] M. Enoch, S. Potter, S. Ison, A strategic approach to financing public transport through property value, Public Money and Management 25 (3) (2005) 147-154.

[21] V.C. Lima Neto, A methodology for estimating the surplus value of property resulting infrastructure interventions in public transport, Master Thesis, Faculty of Engineering, Department of Civil and Environmental Engineering-UNB Brasília, 2006. (in Portuguese)

[22] M.L. Piza, P. Santoro, R. Cymbalista, City Statute: A Reading from the Perspective of Recovery of Land Valuation, in: P. Santoro (org.), F. Furtado, M.L. Piza, M.O. Smolka, R. Cymbalista (Eds.), Social Management of Land Appreciation, Polis, São Paulo, 2004. (in Portuguese)

[23] FJP-João Pinheiro Foundation, Center for Statistics and Information of João Pinheiro Foundation (CEI/FJP), 2009, http://www.fjp.mg.gov.br//index.php?option=com_conten t\& task=view\&id=875\&Itemid=97 (accessed July 22, 2009). (in Portuguese)

[24] IBGE-Brazilian institute of Geography and Statistics, 2008, http://www.ibge.gov.br /cidadesat /topwindow.htm?1 (accessed Feb. 10, 2008). (in Portuguese) 